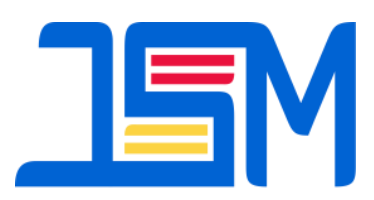

Jambura Science Of Management
JAMBURA SCIENCE OF MANAGEMENT

Homepage : http://ejurnal.ung.ac.id/index.php/jsm

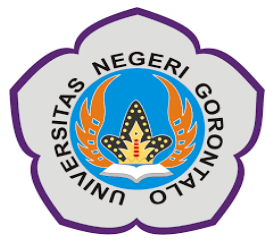

\title{
Analysis Of Financial Performance Using Du Pont System Approach
}

\author{
Moh MF Ginda Male ${ }^{1}$, Lanto Miriatin amali ${ }^{2}$, Meriyana Fransisca Dungga ${ }^{3}$ \\ ${ }^{1,2,3}$ Faculty of Economics, Gorontalo State University \\ E-Mail:Cmale601@gmail.com
}

\begin{abstract}
:
The research was conducted to be used as an evaluation of financial performance using analysis measurement of Du Pont System with quantitative descriptive approach. The analysis was more thorough and it could identify how strong of relationship of profit margin, asset turnover, use of debt and ROI on ROE at textile and garment industry company listed in IDX during 2015-2017 periods which encompassed PT Argo Pantes Tbk, PT Century Textile Industry Tbk, PT Eratex Djaja Tbk, PT Ever Shine Textile Industry Tbk, PT Panasia Indo Resources Tbk, PT Asia Pasific Investama Tbk, PT Asia Pasific Fibers Tbk, and PT Sri Rejeki Isman Tbk by using Du Pont System analysis, with variabels of NPM, TATO, ROI and ROE. The finding of research showed that ROE and ROI at textile and garment industry listed in IDX for 2015-2017 periods was less good due to only 3 companies out of 8 which had very good result of ROI and ROE which were PT. Eratex Djaja Tbk, PT Sri Rejeki Isman Tbk and PT Asia Pasific Investama Tbk and it meant the financial performance was good. Meanwhile the rest 5 companies always showed negative value and result of ROI and ROE was less good with one company for being the lowest namely PT Panasia Indoe Resources Tbk which showed the value of ROI and ROE that was prone to decline year by year.
\end{abstract}

\section{Keywords: Financial Performance; Financial Statement; Du Pont System}

The current millennial era that is always pursuing pride in certain brands makes the industrial technology revolution 4.0 that changes the economy, jobs and even society itself increasingly plays an important role in economic growth in various parts of the world, including Indonesia. Profit or profit is an important means to maintain the survival of the company, financial statements can provide information about the company's financial condition. Financial statement analysis can help companies to plan in the future.

Measurement methods commonly used to measure financial performance include: Ratio Analysis, Market Value Added (MVA), Economic Value added (EVA), Balance Score Card / BSC, Analysis of Capital Assets, Management, Equity and Liquidity (CAMEL) and Du Pont System (Warsono, 2003: 24).

From the description of the method above, the company can measure financial 
performance using financial ratios, namely focusing on the calculation of Return On Investment (ROI) and Return On Equity (ROE), because the calculation of ROI and ROE can show the effective and efficient financial performance of a company.

This study uses the Du Pont System analysis tool. Du Pont System is an analysis that shows debt, asset turnover and profit margin combined to determine ROE (Sudana, 2011: 24). This can provide several advantages, because we can see firsthand the factors that affect ROE, namely profits on sales components (net profit margin), efficient use of assets (total assets turnover), and the use of leverage (debt ratio) ( Syamsudin, 2013: 65). The higher the ROI and ROE the better the performance of the company. This ROE number will provide important information when compared to the comparison used as a standard. So the comparison of ROE values for several consecutive periods will be more accurate. This study discusses the financial performance of several textile and garment industry companies listed on the Indonesia Stock Exchange. There are 18 textile and garment industry companies listed on the Indonesia Stock Exchange, but 9 of them use sharia principles, 9 of which are conventional principles and 1 conventional company is only registered in 2017, so it is not appropriate to compare all of these companies. So the researchers only took 8 sample companies that used conventional principles and published 3year financial statements for the period 2015-2017, namely PT Argo Pantes Tbk, PT Century Textile Industry Tbk, PT
Eratex Djaja Tbk, PT Ever Shine Textile Industry Tbk, PT Panasia Indo Resources Tbk, PT Asia Pacific Investama Tbk, PT Asia Pacific Fibers Tbk, and PT Sri Rejeki Isman Tbk. The purpose of this study is to assess financial performance based on Du Pont System and to assess the company's financial performance based on the criteria of a very good and poor company.

\section{Financial performance}

\section{Financial Performance Analysis}

Financial performance analysis is an analysis of company performance that explains various relationships and financial indicators aimed at showing changes in financial conditions or operating achievements in the past and helps illustrate the trend pattern of change (Fahmi, 2013: 50).

\section{Objectives of Financial Performance} Analysis

According to Munawir (2010: 13-33)

there are several objectives of measuring financial performance, including:

a. To determine the level of company liquidity

b. To find out the solvency level of the company

c. To determine the level of profitability and profitability of the company

d. To find out the stability of the company's business

3. Steps in Analyzing Financial Performance

According to Irham Fahmi (2014: 3), there are 5 (five) stages in analyzing the financial performance of a company in general, namely: 
a. Reviewing financial report data

b. Perform calculations

c. Do a comparison of the results of the calculation that has been obtained

d. Interpreting various problems found

e. Search for and provide solutions to problems (problems) found in various problems

\section{Financial statements}

\section{Analysis of Financial Statements}

Financial statements are information that describes the financial condition of a company, and further information can be used as an illustration of the company's financial performance (Fahmi, 2015: 21).

\section{Purpose of Financial Statements}

According to Kasmir (2016: 87) in practice there are several objectives for the preparation and preparation of financial statements, namely:

a. Provide information about the type and amount of assets (assets) owned by the company at this time;

b. Provide information about the type and amount of liabilities and capital owned by the company at this time;

c. Provide information about the type and amount of income obtained in a certain period;

d. Provide information about the amount of costs and types of costs incurred by the company in a certain period;

e. Providing information about changes that occur to assets, liabilities and company capital; f. Provide information about the performance of company management in a period;

g. Providing information about notes to financial statements;

h. Other financial information.

\section{Types and Financial Reports}

Kasmir (2016: 67) states that a financial report generally consists of 5 types, namely:

a. Balance sheet

b. Income statement

c. Statement of changes in capital

d. Cash inflow statement

e. Note to Financial Statements

\section{Interested Parties with Financial} Reports

According to Kasmir (2012: 19) the parties that have an interest in the financial statements are as follows:

a. Owner;

b. Management;

c. Creditors;

d. Government, and

e. Investor.

Financial Report Analysis Methods and Techniques

The commonly used financial statement analysis method, namely:

a. Vertical Analysis (static)

b. Horizontal Analysis (dynamic)

c. Common Size Analysis

d. Index Analysis

e. Financial Ratio Analysis

f. Analysis of Du Pont System

\section{Analysis of Du Pont System}

\section{Definition of Du Pont System}

Du Pont System analysis is an analysis that shows debt, asset turnover and 
profit margin combined to determine ROE (Sudana, 2011: 24). According to Munawir (2007: 91) in Azizah (2015: 4) citing there are several uses of analyzing financial statements using the Du Pont System method, namely:

a. As one of its principal uses, it is a comprehensive nature.

b. Can be used to measure the profitability of each product produced by the company.

c. Can compare the efficiency of the use of capital in companies with other similar companies.

d. To measure the efficiency of the actions of a unit or section.

e. Can be used for control and planning purposes.

2. Advantages and Weaknesses of the Analysis of Du Pont System

According to Munawir (2010: 91-93), the superiority of $\mathrm{Du}$ Pont System's analysis includes:

a. As one of the comprehensive financial analysis techniques and management can know the level of efficiency of the utilization of assets.

b. Can compare the efficiency of the use of equity in the company with other similar companies, so that it can be known whether the company is below, the same, or above the average.

c. Can be used to measure the efficiency of actions carried out by the division // section

d. Can be used to measure the profitability of each product produced by the company so that it knows which products are potential.

e. In analyzing financial statements using a more integrative approach and using financial statements as an element of analysis.

Meanwhile, the weaknesses of Du Pont System's analysis are:

a. The ROI of a company is difficult compared to the ROI of other similar companies. This is because of differences in accounting practices used.

b. Another disadvantage of this analysis technique is that there is a fluctuation in the value of money (purchasing power).

c. By using ROI alone, it cannot be used to make comparisons between two problems.

\section{Calculation of Analysis of Du Pont System}

\section{a. Return On Equity (ROE)}

This ratio shows the ability of the company to generate profits by using the company's own capital (Sudana, 2011: 22). ROE can be calculated by the following formula:

$$
\text { ROE }=R O A x \frac{\text { Total Assets }}{\text { Total Equity }}
$$

\section{b. Return On Investment (ROI)}

According to Sudana (2011: 59) this ratio shows the company's ability to use all assets owned by the company to generate profits. ROI or ROA calculated using the Du Pont System (Harahap, 2015: 335) approach, namely:

Return On Invesment $=$ NPM x TATO 


\section{c. Net Profit Margin (NPM)}

Net profit margin describes the amount of net profit obtained by the company on each sale made. In other words, this ratio measures net income after tax on sales (Harahap, 2015). NPM can be calculated by the following formula:

\section{$\underline{\text { Laba Bersih Setelah Pajak (EAT) }}$} Penjual an Bersih (Sales)

\section{d. Total Assets Turn Over (TATO)}

According to Harahap (2015: 309) Total Assets Turnover is a ratio that shows total assets turnover measured by sales volume in other words how far the ability of all assets creates sales. TATO can be calculated with the following formula:

\begin{tabular}{c} 
Sales \\
Total Assets \\
\hline
\end{tabular}

\section{METHOD}

While the study used is deemed difficult with a quantitative approach. This research is carried out in the textile and garment industry that has been registered on the National Burma Hospital in 20152017. The research methods used are as follows:

1. Analysis of Du Pont System, the indicators are Return On Investment (ROI) and Return On Equity (ROE).

2. Financial performance, conduct a comparative analysis of the financial performance of textile and garment companies in 2015-2017. Indicators of financial performance are income statements and balance sheets.

The population used is all textile and garment industry companies listed on the Stock Exchange in 2015-2017, the company has complete and published financial statements. The sampling technique is using purposive sampling. According to the results of purposive sampling, the sample used was 8 (eight) which included PT Argo Pantes Tbk, PT Century Textile Industry Tbk, PT Eratex Djaja Tbk, PT Ever Shine Textile Industry Tbk, PT Panasia Indo Resources Tbk, PT Asia Pasific Investama Tbk, PT Asia Pasific Fibers Tbk and PT Sri Rejeki Isman Tbk. The type of data is secondary data and data collection techniques that are carried out, namely using the documentation method in the form of notes from financial statements published by the Indonesia Stock Exchange. There are several stages of data analysis performed:

1. Du Pont System's calculation analysis includes:

a. Net Profit Margin (NPM)

b. Total Assets Turn Over (TATO)

c. Return On Investment (ROI)

d. Return On Equity (ROE)

2. Comparing the financial performance of textile and garment industry companies with Du Pont System

3. Calculation of the average industry in the textile and garment industry

4. Draw conclusions from the results of $\mathrm{Du}$ Pont System's calculations to find out the company's financial performance is very good or not good. 


\section{RESULTS AND DISCUSSION}

ROI Comparison of Textile and Garment Industry Companies

The results of the financial performance measurement of textile industry companies listed on the Indonesia Stock Exchange with ROI using the Du Pont System analysis can be described through the following table:

Table 1 ROI Recapitulation Results of Textile and Garment Industry Companies

\begin{tabular}{|c|c|c|c|c|}
\hline KODE EMITEN & $\mathbf{2 0 1 5}$ & $\mathbf{2 0 1 6}$ & $\mathbf{2 0 1 7}$ & Total \\
\hline ARGO & $-8.46 \%$ & $-21.82 \%$ & $-15.54 \%$ & $-45.83 \%$ \\
\hline CNTB & $-1.38 \%$ & $3.99 \%$ & $-3.57 \%$ & $-0.96 \%$ \\
\hline ERTX & $10.09 \%$ & $5.44 \%$ & $3.58 \%$ & $19.11 \%$ \\
\hline ESTI & $-18.45 \%$ & $6.33 \%$ & $-2.77 \%$ & $-14.89 \%$ \\
\hline HDTX & $-6.21 \%$ & $-5.35 \%$ & $-15.69 \%$ & $-27.25 \%$ \\
\hline MYTX & $-6.88 \%$ & $-9.96 \%$ & $15.49 \%$ & $-1.35 \%$ \\
\hline POLY & $-7.05 \%$ & $-5.26 \%$ & $-2.45 \%$ & $-14.76 \%$ \\
\hline SRIL & $7.06 \%$ & $6.16 \%$ & $5.51 \%$ & $18.73 \%$ \\
\hline Rata-rata industri & $\mathbf{- 3 . 9 1 \%}$ & $\mathbf{- 2 . 5 6 \%}$ & $\mathbf{- 1 . 9 3 \%}$ & $\mathbf{- 8 . 4 0 \%}$ \\
\hline
\end{tabular}

From table 1 shows the value of ROI in 2015 there are 3 companies that have a level of return on investment above the industry average per year, where the highest ROI value is PT Eratex Djaja Tbk which is $10.09 \%$, then PT Sri Rejeki Isman Tbk with the results ROI of $7.06 \%$ and PT Century Textile Industry Tbk showed negative conditions of $-1.38 \%$ but were above the industry average. And 5 other companies showed ROI results that were below the industry average per year with the lowest ROI, namely PT Ever Shine Textile Industry Tbk amounting to $18.45 \%$.
Whereas in 2016 there were 4 companies which showed ROI results above the industry average per year. Where the highest ROI is PT Ever Shine Textile Industry Tbk, which is equal to $6.33 \%$, which in 2015 was the company with the lowest ROI, then PT Sri Rejeki Isman Tbk with an ROI of $6.16 \%$, PT Eratex Djaja Tbk which was equal to 5 , 44\% and PT Century Textile Industry Tbk with a ROI of $3.99 \%$. With the results of the lowest ROI of PT Argo Pantes Tbk, which amounted to $-21.82 \%$. In 2017 there were only 3 companies that showed ROI results above the industry average. Where the highest ROI was PT Asia Pasific 
Investama Tbk, which amounted to 15.49\%, then PT Sri Rejeki Isman Tbk with an ROI of $5.51 \%$, and PT Eratex Djaja Tbk which was $3.58 \%$. With the lowest ROI, namely PT Panasia Indo Resources Tbk amounting to $-15.69 \%$.

\section{ROE Comparison of Textile and Garment Industry Companies}

The results of the financial performance measurement of textile industry companies listed on the Indonesia Stock Exchange with ROE using the Du Pont System analysis can be described through the following table:

Table 2 ROE Recapitulation Results of Textile and Garment Industry Companies

\begin{tabular}{|c|c|c|c|c|}
\hline KODE EMITEN & $\mathbf{2 0 1 5}$ & $\mathbf{2 0 1 6}$ & $\mathbf{2 0 1 7}$ & Total \\
\hline ARGO & $34.83 \%$ & $44.47 \%$ & $21.17 \%$ & $100.47 \%$ \\
\hline CNTB & $-34.17 \%$ & $49.60 \%$ & $-115.05 \%$ & $-99.62 \%$ \\
\hline ERTX & $31.19 \%$ & $14.33 \%$ & $11.88 \%$ & $57.40 \%$ \\
\hline ESTI & $-80.51 \%$ & $19.36 \%$ & $-11.57 \%$ & $-72.72 \%$ \\
\hline HDTX & $-217.16 \%$ & $-142.30 \%$ & $-189.82 \%$ & $-549.28 \%$ \\
\hline MYTX & $23.54 \%$ & $17.44 \%$ & $153.51 \%$ & $194.49 \%$ \\
\hline POLY & $1.77 \%$ & $1.30 \%$ & $0.60 \%$ & $3.67 \%$ \\
\hline SRIL & $19.98 \%$ & $17.63 \%$ & $14.87 \%$ & $52.48 \%$ \\
\hline Rata-rata industri & $\mathbf{- 2 7 . 5 7 \%}$ & $\mathbf{2 . 7 3 \%}$ & $\mathbf{- 1 4 . 3 0 \%}$ & $\mathbf{- 3 9 . 1 4 \%}$ \\
\hline
\end{tabular}

From table 2 shows that ROE in 2015 there are 5 companies that have a level of return on equality above the industry average per year, where the highest ROE value is PT Argo Pantes Tbk which is equal to $34.83 \%$, then PT Eratex Djaja Tbk with results ROE of $31.19 \%$, PT Asia Pacific Investama with ROE results of $23.54 \%$, PT Sri Rejeki Isman Tbk which is $19.98 \%$ and PT Asia Pacific Fibers Tbk which is $1.77 \%$. And 3 other companies are below the industry average, namely PT Century Textile Industry Tbk, which is $-34.17 \%$, PT Ever Shine Textile Industry Tbk is $-80.51 \%$ and PT Panasia Indo Resources is $-217.16 \%$, which means performance the company in producing profits from all of its assets is less efficient.

In 2016 there was only 1 company that showed ROI results far below the industry average per year, namely PT Panasia Indo Resources Tbk with ROE results showing a negative amount of $142.30 \%$, which means that this value is very far from the industry average per year 
and showing poor company performance. And the remaining 7 companies showed positive ROE results that were above the industry average. In 2017 there were 6 companies which showed ROE results above the industry average. Where the highest ROI is PT Asia Pasific Investama Tbk, which is equal to $64.83 \%$, then PT Argo Pantes Tbk with ROE of 33.49\%, PT Eratex Djaja Tbk which is $19.13 \%$, PT Sri Rejeki Isman Tbk which is 17 , 49\%, PT Asia Pacific Fibers Tbk with ROE of $1.22 \%$ and PT Ever Shine Textile Industry Tbk amounting to $-11.57 \%$. And 2 other companies namely PT Century Textile Industry Tbk with ROE of $-115.05 \%$, PT Panasia Indo Resources amounting to -
$189.82 \%$ which is below the industry average in 2017 which means the company's ability to earn profits through capital owned companies earn profits through capital owned by companies less efficiently.

Recapitulation of ROI and ROE of Textile and Garment Industry Companies

Here, the researcher presents an assessment of the company's financial performance with a comparison of Return on Investment (ROI) and Return On Equity (ROE) of each textile and garment industry company that is listed on the IDX in the period 2015 to 2017:

Table 3 Results of Recapitulation of Companies Included in the Good Criteria

\begin{tabular}{|c|c|c|c|c|c|}
\hline \multirow{2}{*}{ Perusahaan } & Rasio & $\begin{array}{c}\text { Total } \\
\mathbf{2 0 1 5 - 2 0 1 7}\end{array}$ & $\begin{array}{c}\text { Rata-rata } \\
\text { Industri }\end{array}$ & Keterangan & $\begin{array}{c}\text { Companie } \\
\text { Criteria }\end{array}$ \\
\hline \multirow{2}{*}{ PT Eratex Djaja Tbk } & ROI & $19.11 \%$ & $\mathbf{- 8 , 4 0 \%}$ & $\begin{array}{c}\text { Di atas rata- } \\
\text { rata }\end{array}$ & \multirow{2}{*}{ GOOD } \\
\cline { 2 - 5 } & ROE & $57,40 \%$ & $\mathbf{- 3 9 , 1 4 \%}$ & $\begin{array}{c}\text { Di atas rata- } \\
\text { rata }\end{array}$ & \\
\hline \multirow{2}{*}{$\begin{array}{c}\text { PT Sri Rejeki Isman } \\
\text { Tbk }\end{array}$} & ROI & $18.73 \%$ & $\mathbf{- 8 , 4 0 \%}$ & $\begin{array}{c}\text { Di atas rata- } \\
\text { rata }\end{array}$ & \multirow{2}{*}{ GOOD } \\
\cline { 2 - 5 } & ROE & $52.48 \%$ & $\mathbf{- 3 9 , 1 4 \%}$ & $\begin{array}{c}\text { Di atas rata- } \\
\text { rata }\end{array}$ & \\
\hline \multirow{2}{*}{$\begin{array}{c}\text { PT Asia Pasific } \\
\text { Investama Tbk }\end{array}$} & ROI & $-1.35 \%$ & $\mathbf{- 8 , 4 0 \%}$ & $\begin{array}{c}\text { Di atas rata- } \\
\text { rata }\end{array}$ & \multirow{2}{*}{ GOOD } \\
\cline { 2 - 5 } & $\mathbf{R O E}$ & $194.49 \%$ & $\mathbf{- 3 9 , 1 4 \%}$ & $\begin{array}{c}\text { Di atas rata- } \\
\text { rata }\end{array}$ & \\
\hline
\end{tabular}

Table 4 Results of Recapitulation of Companies Included in the Poor Criteria

\begin{tabular}{|c|c|c|c|c|c|}
\hline Perusahaan & Rasio & $\begin{array}{c}\text { Total 2015- } \\
\mathbf{2 0 1 7}\end{array}$ & $\begin{array}{c}\text { Rata-rata } \\
\text { Industri }\end{array}$ & Keterangan & $\begin{array}{c}\text { Kriteria } \\
\text { Perusahaan }\end{array}$ \\
\hline PT Argo Pantes Tbk & ROI & $-45.83 \%$ & $\mathbf{- 8 , 4 0 \%}$ & $\begin{array}{c}\text { Di bawah rata- } \\
\text { rata }\end{array}$ & POOR \\
\hline
\end{tabular}




\begin{tabular}{|c|c|c|c|c|c|}
\hline & ROE & $100.47 \%$ & $-39,14 \%$ & Di atas rata-rata & \\
\hline \multirow{2}{*}{$\begin{array}{c}\text { PT Asia Pasific Fibers } \\
\text { Tbk }\end{array}$} & ROI & $-14.76 \%$ & $-8,40 \%$ & $\begin{array}{c}\text { Di bawah rata- } \\
\text { rata }\end{array}$ & \multirow[t]{2}{*}{ POOR } \\
\hline & ROE & $3.67 \%$ & $-39,14 \%$ & Di atas rata-rata & \\
\hline \multirow{2}{*}{$\begin{array}{l}\text { PT Ever Shine Textile } \\
\text { Industry Tbk }\end{array}$} & ROI & $-14.89 \%$ & $-8,40 \%$ & $\begin{array}{c}\text { Di bawah rata- } \\
\text { rata }\end{array}$ & \multirow{2}{*}{ POOR } \\
\hline & ROE & $-72.72 \%$ & $-39,14 \%$ & $\begin{array}{c}\text { Di bawah rata- } \\
\text { rata }\end{array}$ & \\
\hline \multirow{2}{*}{$\begin{array}{l}\text { PT Century Textile } \\
\text { Industry Tbk }\end{array}$} & ROI & $-0.96 \%$ & $-8,40 \%$ & Di atas rata-rata & \multirow[b]{2}{*}{ POOR } \\
\hline & ROE & $-99.62 \%$ & $-39,14 \%$ & $\begin{array}{c}\text { Di bawah rata- } \\
\text { rata }\end{array}$ & \\
\hline \multirow{2}{*}{$\begin{array}{l}\text { PT Panasia Indo } \\
\text { Resources Tbk }\end{array}$} & ROI & $-27.25 \%$ & $-8,40 \%$ & \begin{tabular}{|c|}
$\begin{array}{c}\text { Di bawah rata- } \\
\text { rata }\end{array}$ \\
\end{tabular} & \multirow[t]{2}{*}{ POOR } \\
\hline & ROE & $-549.28 \%$ & $-39,14 \%$ & Di atas rata-rata & \\
\hline
\end{tabular}

Based on the table above, the results of the recapitulation of the ratio of Return on Investment (ROI) and Return On Equity (ROE) to textile and garment industry companies as a whole from the 8 companies studied financial performance both experienced fluctuations or ups and downs in each year. Whereas seen from the percentage of industry average during the period studied, that the company with the best financial performance position is PT Eratex Djaja Tbk and PT Sri Rejeki Isman Tbk and PT Asia Pacific Investama which are the companies with the best financial performance compared to companies others in the same industry.

This can be seen from the value of ROI and ROE in 2015-2017 which the company achieved showed very good performance despite a decline, namely PT Eratex Djaja by $10.09 \%, 5.44 \%$, and $3.58 \%$ for ROI and $31.19 \%, 14.33 \%$ and $11.88 \%$ for ROE, PT Sri Rejeki Isman Tbk at $7.06 \%, 6.16 \%$ and $5.51 \%$ for ROI and
$19.98 \%, 17.63 \%$ and $14.87 \%$ for ROE, and PT Asia Pasific Investama Tbk with ROI of $-6.88 \%,-9.96 \%, 15.49 \%$ and ROE results of $23.54 \%, 17.44 \%, 153.51 \%$.

While companies with poor financial performance for the 2015-2017 period are PT Panasia Indo Resources Tbk, PT Ever Shine Textile Industry Tbk, PT Century Textile Industry Tbk, PT Argo Pantes Tbk and PT Asia Pasific Fibers Tbk. This is because the ROE produced by the company has decreased from year to year, ROE is influenced by ROI and Equity Multiplier, where ROI generated by companies has declined from year to year, and company Equity Multiplier is also getting worse from year to year.

\section{CONCLUSION}

The textile and garment industry companies with conventional principles listed on the Indonesia Stock Exchange for the 2015-2017 period with good financial performance are PT Eratex Djaja Tbk, PT 
Sri Rejeki Isman Tbk, PT Asia Pacific Investama Tbk with ROI and ROE values that are above the industry average from year to year. While companies with poor financial performance, PT Argo Pantes Tbk, PT Century Textile Industry Tbk, PT Ever Shine Textile Industry Tbk, PT Panasia Indo Resources Tbk and PT Asia Pasific Fibers Tbk.

The financial performance of the textile and garment industry companies listed on the Indonesia Stock Exchange in the 2015-2017 period is not good enough. Overall, from 8 companies, there were only 3 companies that were declared good and the other 5 companies were stated to be bad. This is caused by fluctuating ROI and ROE and tends to show negative conditions, and is influenced by the results of NPM, TATO and Equity Multiplier due to a decline in the value of net income, return on company assets and shareholder equity.

\section{REFERENCES}

Atmaja, Lukas Setia. 2003. Manajemen Keuangan. Edisi Ketiga. Yogyakarta: ANDI

Azizah, dkk. 2015. "Analisis Kinerja Keuangan Perusahaan (Perbandingan Penggunaan Analisis Rasio Keuangan dan Du Pont System) Studi Pada PT. Unilever Indonesia Tbk dan Anak Perusahaan Yang Terdaftar di Bursa Efek Indonesia Periode 2007-2013". Jurnal Administrasi Bisnis (JAB) Vol.25 No.2 Agustus 2015.
Bursa Efek Indonesia. "Laporan Keuangan Perusahaan Tercatat". Diakses pada tanggal 5 Februari 2019 dari https://www.idx.co.id/perusahaantercatat/laporan-keuangan-dantahunan/

Djarwanto, Ps. 2010. Pokok-Pokok Analisa Laporan Keuangan. Edisi Kedua. Yogyakarta: Badan Penerbit Fakultas Ekonomi

Fahmi, Irham. 2013. Analisis Laporan Keuangan. Cetakan Ketiga. Bandung: Alfabeta.

Firmansyah, Alif Iqbal dan Achmad Husaini. 2018. Analisis Kinerja Keuangan Perusahaan Dengan Metode Dupont System Pada Perusahaan Farmasi Di Bursa Efek Indonesia (Studi Pada Perusahaan Pt. Merck, Tbk. Tahun 2012-2016). Jurnal Administrasi Bisnis (JAB) Vol. 61 No.3 Agustus 2018.

Harahap, Sofyan Syafri. 2013. Analisis Kritis atas Laporan Keuangan. Edisi Kesepuluh. Jakarta: Rajawali Pers.

Harjito, Agus dan Martono. 2014. Manajemen Keuangan. Cetakan Keempat. Yogyakarta: EKONISIA.

Kasmir. 2016. Analisis Laporan Keuangan. Cetakan Kesembilan. Jakarta: PT. Raja Grafindo Persada. Kuntri, Bernardeth dkk. 2016. Analisis Kinerja Keuangan Perusahaan Menggunakan Du Pont System (Studi Pada Industri Semen Di Indonesia Yang Terdaftar Di Bursa Efek Indonesia Periode 2012-2014). 
Jurnal Administrasi Bisnis (JAB)

Vol. 40 No.2 November 2016.

Mohideen, O.M Haja dan M. Parveen. 2014. "A Study On Predicting Financial Performance Using Duo Pont Analysis In Cipla Pharmaceutical Company". International Journal of Accounting and Financial Management Research (IJAFMR) Vol.4 Issue 5, Oct 2014, Hal 39-44.

Munawir S. 2010. Analisis Laporan Keuangan, Edisi Keempat. Yogyakarta : Liberty.

Nazir, Moh. 2005. Metode Penelitian. Jakarta: Ghalia Indonesia.

Riduwan. 2014. Metode dan Teknik Menyusun Tesis. Cetakan Kesepuluh. Bandung: ALFABETA.

Sahamok. "Sub Sektor Tekstil dan Garment BEI". Diakses pada tanggal 19 Desember 2018 dari https://www.sahamok.com/emiten/se ktor-aneka-industri/sub-sektor-

tekstil-garment/

Saraswati, Ni Made D. Putri dkk. 2015. Analisis Du Pont System Sebagai Salah Satu Mengukur Kinerja Keuangan (Studi Pada Perusahaan Rokok Yang Listing di Bursa Efek Indonesia Tahun 2011-2013). Jurnal Administrasi Bisnis (JAB) Vol.23 No.1 Juni 2015.

Sudana, I Made. 2011. Manajemen Keuangan Perusahaan Teori dan Praktik. Jakarta: Erlangga

Sulistiyo, Liliek N. 2017. "Analisis Sistem Du Pont Sebagai Salah Satu Alat Untuk Menilai Kinerja Keuangan Perusahaan (Studi Pada Perusahaan Property Real Estate Yang Terdaftar di BEI Tahun 2010-2014)". Jurnal Akuntansi, Prodi Akuntansi - FEB, UNIPMA, Vol.1 No.1 Oktober 2017. Syamsuddin, Lukman. 2013. Manajemen Keuangan Perusahaan. PT. Raja Grafindo Persada, Jakarta. 